\title{
Impact of co-facilitated information programmes on outcomes for service users and family members: the EOLAS programmes (paper 2) - Corrigendum
}

\author{
A. Higgins, D. Hevey, P. Gibbons, C. O'Connor, F. Boyd, P. McBennett and M. Monaghan \\ doi: http:/ /dx.doi.org/10.1017/ipm.2015.69, Published by Cambridge University Press, 22 January, 2016.
}

First published online 9 Febraury 2016

The name of the author, M. Monahan, was incorrectly presented as M. Monaghan in this article. The correct spelling is Monahan.

\section{Reference}

Higgins A, Hevey D, Gibbons P, O' Connor C, Boyd F, McBennett P, Monaghan M. Impact of co-facilitated information programmes on outcomes for service users and family members: the EOLAS programmes (paper 2). Irish Journal of Psychological Medicine, available on CJO 2016. doi:10.1017/ipm.2015.69. 